\title{
The site of self-incompatibility action in cupuassu (Theobroma grandiflorum) ${ }^{1}$
}

\author{
ALESSANDRA R. RAMOS ${ }^{2}$, GIORGINI A. VENTURIERI ${ }^{3,6}$, SILVIA M. CUCO $^{4}$ and \\ NEUZA M. CASTRO
}

(received: May 13, 2004; accepted: July 22, 2005)

\begin{abstract}
The site of self-incompatibility action in cupuassu (Theobroma grandiflorum)). Cupuassu (Theobroma grandiflorum (Willd. ex Spreng.) Schumann) is a fruit tree that is attracting attention in Brazil and also in other tropical countries. Its pulp is used to prepare ice-cream, juices, jellies and many other home-made sweets. This species has a very low fecundity, attributed to problems with pollination and self-incompatibility, noted as being restrictive to the agronomic productivity of the species. Controlled pollinations between compatible and incompatible parents were made and flowers were collected at three times: 24, 48 and $72 \mathrm{~h}$ after pollinations, during the floral seasons of 1995 and 1998. In flowers collected $24 \mathrm{~h}$ after pollination, in both compatible and incompatible crosses, around $70 \%$ of ovules showed egg apparatus without evidences of sperm cell delivery; nevertheless some pollen tubes had been observed. Ovaries collected at $48 \mathrm{~h}$ showed different behaviors according to the type of cross. In the compatibles, $35 \%$ of ovules did not show evidences of gamete fusion. In incompatible crosses this number rose to $50 \%$. Collected ovaries with $72 \mathrm{~h}$, from compatible and incompatible crosses, showed respectively $1.2 \%$ and $14.2 \%$ of the ovules with the egg apparatus and polar nuclei only. In these ovaries, for the two types of crosses, the presence of sperm nuclei was common and the zygote was still undivided. The incompatibility action is occurring after fertilization, in a late self-incompatibility action.
\end{abstract}

Key words - controlled pollination, infertility, ovule clearing

RESUMO - (O sítio de ação da auto-incompatibilidade no Cupuaçu (Theobroma grandiflorum)). O cupuaçu (Theobroma grandiflorum (Willd. ex Spreng.) Schumann) é uma fruteira que vem despertando atenção tanto no Brasil como em outros países tropicais, cuja polpa é usada na fabricação de sorvetes, sucos, geléias e vários doces caseiros. Esta espécie possui baixíssima fecundidade, atribuída a problemas de polinização e auto-incompatibilidade, apontados como restritivos à produtividade da espécie. Cruzamentos controlados com parentais compatíveis e incompatíveis foram realizados e as flores coletadas a 24, 48 e 72 horas após a polinização, nos períodos de florescimento dos anos de 1995 e 1998. Nas flores coletadas 24 horas após a polinização, tanto nos cruzamentos compatíveis quanto incompatíveis, cerca de $70 \%$ dos óvulos não apresentaram sinais da descarga espermática, embora alguns tubos polínicos tenham sido observados. Os ovários coletados 48 horas após a polinização apresentaram comportamento diferente dependendo do tipo de cruzamento. Nos compatíveis, 35\% dos óvulos não mostraram indícios de fusão gamética e nos incompatíveis 50\% comportaram-se da mesma forma. Ovários coletados 72 horas após a polinização, resultantes de cruzamentos compatíveis e incompatíveis, apresentaram 1,2\% e 14,2\% dos óvulos com apenas o aparato oosférico e os núcleos polares, respectivamente. Nestes óvulos, para os dois tipos de cruzamentos, foi comum a presença de núcleos endospermáticos e do zigoto ainda indiviso. O estudo mostrou que a ação de incompatibilidade ocorre após a fertilização, num mecanismo de ação tardia de auto-incompatibilidade.

Palavras-chave - clarificação de óvulos, infertilidade, polinização controlada

\section{Introduction}

Cupuassu (Thebroma grandiflorum (Willd. ex Spreng.) Schumann - Sterculiaceae) is a fruit tree, native

1. Part of the MS thesis of the first author.

2. Universidade Federal do Pará, Centro de Ciências Biológicas, Departamento de Genética (as a fellow of Capes), Caixa Postal 8607, 66075-900 Belém, PA, Brazil.

3. Universidade Federal do Pará, Centro de Ciências Biológicas, Departamento de Genética, Caixa Postal 8607, 66075-900 Belém, PA, Brazil, Presently at Universidade Federal de Santa Catarina, Centro de Ciências Biológicas, Departamento de Biologia Celular, Embrilogia e Genética, Campus de Trindade, 88040-9000 Florianópolis, SC, Brazil.

4. Escola Superior de Agricultura "Luiz de Queiroz", Departamento de Genética, Av. Pádua Dias 11, 13400-970 Piracicaba, SP, Brazil.

5. Universidade Federal de Uberlândia, Instituto de Biologia, 38400-902 Uberlândia, MG, Brazil.

6. Corresponding author: giorgini@ccb.ufsc.br to Southeastern Amazonia, from where it was distributed throughout the Amazon basin by Amerindians and more recently by caboclos, a cultural and/or racial crossing between European and Indigenous populations, and colonizers coming from the South of Brazil (Clement \& Venturieri 1990, Venturieri 1993a).

At present, the species is attracting worldwide attention, thus experiencing rapid expansion into the world market for exotic fruit flavours. Its pulp is currently used in juices, candies and ice creams. It has a strong acid, agreeable flavour and fragrance that is responsible for its rapid increase in popularity. From the seeds it is possible to make a chocolate, similar to the traditional chocolate made with cocoa, but without theobromine, an alkaloid which, according to current nutritional values, is not recommended for the human diet (Venturieri \& 
Aguiar 1988). From the seeds it is also possible to extract a highly digestible fat, which is also suitable for a skin cream preparation (Berbert 1981, Venturieri 1993b).

Of the eight Brazilian species of the genus Theobroma, at least six have problems of fecundity and, consequently, a low fruit bearing rate (Rodrigues \& Venturieri 1997). In cupuassu, the proportion between developed fruits and formed flowers is 1:206 (Falcão \& Lleras 1983). Causes given for the low fecundity are: i) low number of pollinated flowers (around $1.6 \%$ due to the flower's natural barriers); ii) the inefficiency of the pollinator (that is a generalist) and iii) the high number of pollinated flowers that abort due to mechanisms of self-incompatibility and/or the low number of pollen grains deposited on the stigmatic branches (Venturieri 1994, Venturieri \& Ribeiro Filho 1995).

Cupuassu is a predominantly allogamous species with an incompatibility system under genetic control (Venturieri 1994); this is considered by Cuatrecasas (1964) to be a characteristic of the genus Theobroma. Self-incompatibility is pointed to as one of the causes of irregular fruit bearing, mainly on incipient domesticated plants. Cupuassu is a species undergoing domestication and breaking of self-incompatibility is a strategy suggested for increasing fecundity of the trees, thus promoting better and more stable harvests (Venturieri 1994). With the elucidation of the site of incompatibility it is expected that more applied studies could be encouraged, using molecular analyses, to identify possible proteins related to genetic control of abortion, useful to identify involved gene, or genes, on its expression.

Self-incompatibility and cross-incompatibility in cocoa (Theobroma cacao) was recognized from twenties when the wilting and dropping of cherelles was attributed to incompatibility (for a review see Dias \& Rezende (2001) and Free (1993)) but its genetic control and the site where it occurred was first studied by Knight \& Rogers (1955) and Cope (1962). These authors recognized that pollen tubes, from compatible and incompatible crosses, have a similar growth and discharge their spermatic cells at the megagamethophyte, but incompatible gametes fail in the process of fusion with the egg cell, where apparently the incompatible reaction occurs. Cytological investigation made by Cope (1962) showed that, when an incompatible pollinated flower fail to set a fruit, $25 \%, 50 \%$ or $100 \%$ of the ovules in the ovary show no fusion with the male gamete to give a zygote and a triploid primary endosperm. Three complementary loci appears to be involved and have been called as A, B, and S. The first two show simple dominance and recessivity producing a precursor to be complemented by the S locus. When A and/or B loci are, at least heterozygous for the dominant allele, the general precursor substance is produced and on this the $\mathrm{S}$ locus acts. The $\mathrm{S}$ locus system is controlled by five active alleles (S1, S2, S3, S4 and S5), at one locus, exibing dominance (noted by $>$ ) and independence (noted by $=$ ), suggesting that $\mathrm{S} 1>\mathrm{S} 2=\mathrm{S} 3>\mathrm{S} 4>\mathrm{S} 5$ (Knight \& Rogers 1955). An inactive amorth allele for of the $S$ series was also proposed (Cope 1962). For example, pollen and an ovary, that locus $\mathrm{A}$ and $\mathrm{B}$ are active, carrying the same $S$ alleles or independent alleles expressing the same phenotype due to dominance effect, will fail to mate. Crosses that locus A and/or B are inactive will be compatible. Crosses that locus A and B are active but $\mathrm{S}$ are different and not expressing the same phenotype, or homozygous for the inactive amorph $\mathrm{S}$ form, will be compatible. The locus A and B acts before meiosis and the $S$ acts before and after meiosis. So, the breeding system of cocoa has an sporophytic and a gametophytic control.

Self-incompatibility was partially studied in Theobroma grandiflorum by Venturieri (1994) that considered it a true self-incompatible species and with a similar pollen tube growth on compatible and incompatible crosses. The understanding of this mechanism in cupuassu could favor the use of new biotechnological tools to increase its productivity, such as the silencing of genes that control self-incompatibility.

The present work has the objective of pinpointing the site where self-incompatibility is acting in cupuassu, beginning with controlled pollination and tracing the pollen tube growth throughout its penetration into the ovule, gamete fusion and the development of zygotes and embryo formation. Studies were carried out in fertilized ovaries through observations of histological sections and clarified ovules.

\section{Material and methods}

For studies of the breeding system, flower buds where collected from trees of the Theobroma collection ("Basil Bartley" collection), at the "José Haroldo" Experimental Station (ERJOH), in the Municipality of Marituba - PA, Brazil $\left(1^{\circ} 12^{\prime} \mathrm{S}\right.$ and $\left.49^{\circ} 13^{\prime} \mathrm{W}\right)$ belonging to the Executive Commission for Cocoa Crop Planning (Ceplac). Crossing were carried out during the 1995 floral seasons, with three trees, named 182-8, 229-25, 296-1, being evaluated.

Flowers from compatible and incompatible plants (previously identified by Venturieri (1994)) were copiously pollinated, just after anthesis (between 16 and $18 \mathrm{~h}$ ), according to Venturieri \& Ribeiro Filho (1995). From each cross, flowers 
were collected at 24, 48 and 72 hours after pollination (HAP). Twenty ovaries by cross/time after pollination were collected for the studies and their ovaries fixed in F.A.A. $70 \%$, for 24-48 $\mathrm{h}$ and stocked in ethanol $70 \%$ (table 1).

Part of the ovules were isolated and submitted to Methyl Salicylate as a clarifying agents (Cuco 1997). Mayer's Hematoxilin was used as a dye (for five hours) (adapted from Jahier 1992). Treated ovules where poured into micro slide concavities with Methyl Salicylate, covered with micro cover slides and analyzed under phase contrast microscopes.

Another part of the excised ovaries was dehydrated, and included in paraffin or hystoresin, sectioned with a microtome and stained with Heidenhein's Hematoxilin and Toluidine Blue, according to protocols described by Cuco (1992) and Castro (1998), respectively.

Table 1. Number of ovaries obtained in crossing between compatible and incompatible parental of cupuassu, at the floral season of 1995 and collected in three different times after pollination. HAP $=$ hours after pollination.

\begin{tabular}{llllc}
\hline \multirow{2}{*}{ Crossing } & \multirow{2}{*}{ Breeding system } & \multicolumn{3}{c}{ Number of ovaries } \\
\cline { 3 - 5 } & & 24HAP & 48HAP & 72HAP \\
\hline $296-01+\times 229-25 \sigma^{*}$ & Compatible & 20 & 20 & 20 \\
$229-25+\times 226-01 \sigma^{\rightarrow}$ & Compatible & 20 & 20 & 20 \\
$229-25+\times 182-08 \sigma^{\rightarrow}$ & Incompatible & 20 & 20 & 20 \\
\hline
\end{tabular}

The frequency of each cellular class (sperm cells, oosphere, polar nuclei, endosperm and pro-zygote) encountered in the embryo sacs, at different moments after pollination, was evaluated to check: if the pollen tubes delivered sperm cells in the female gametophyte; the time spent between pollination and gamete fusion, and in what phase the incompatibility reaction could be perceived. The Kolmogorov-Smirnov test (Siegel 1975) was applied, to evaluate the significance of eventual differences between the frequency of each cellular class in compatible and incompatible plants, during the different times.

\section{Results}

In $94.3 \%$ of ovules from flowers analyzed prior to anthesis, the megagametophyte showed only the egg apparatus and the two polar nucleus, the antipodals could not be observed and, in $1.4 \%$ of these ovules, the typical structure of the embryo sac for this species, with five nuclei, also could not be seen. Despite their normal appearance, there were indications that the process of differentiation was not complete.

The polarization of the egg apparatus cells showed no variation, with apical vacuolization in synergids and basal vacuolization at the oosphere (figure 1A). The nucellus, which was not consumed during the
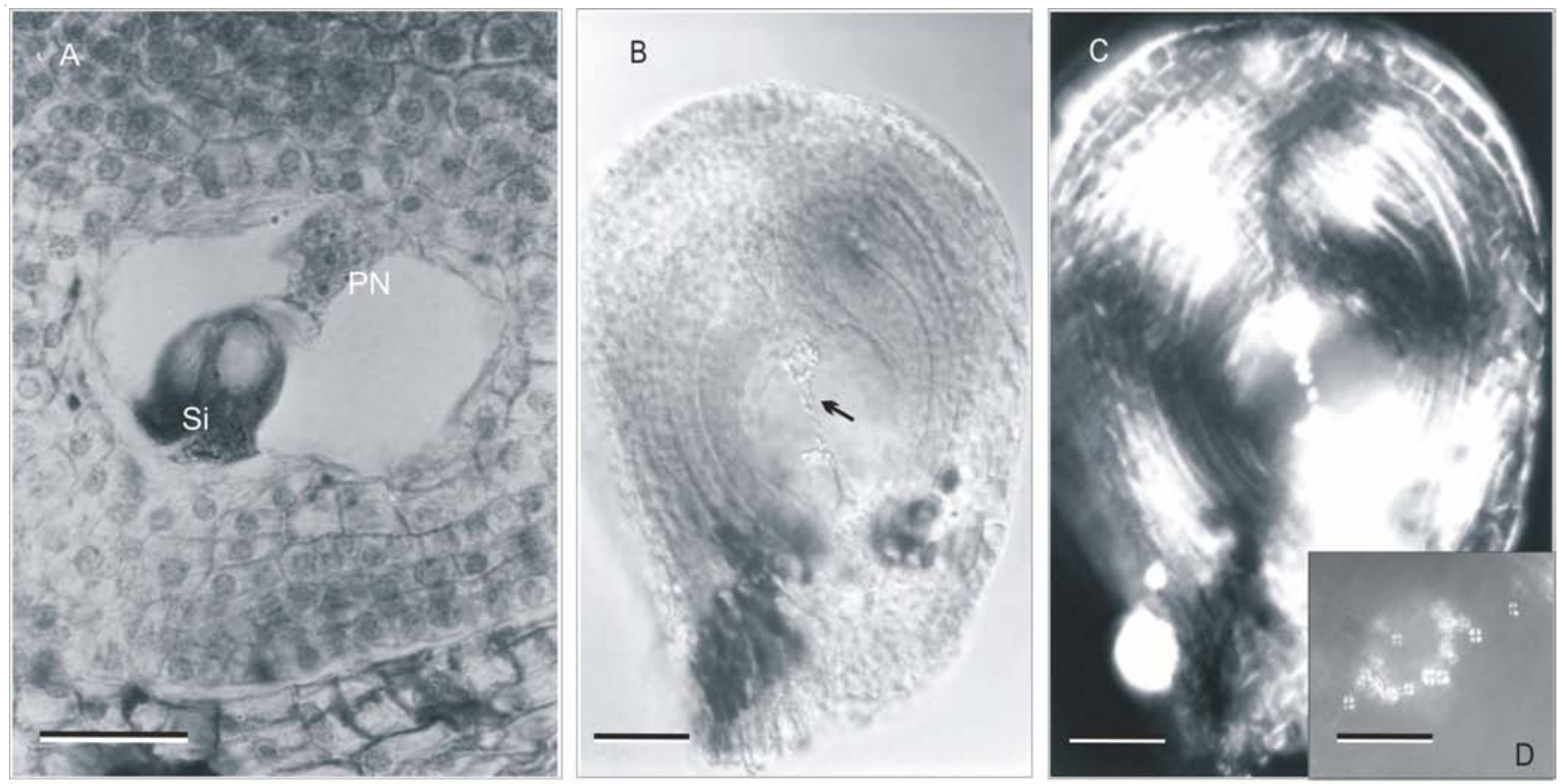

Figure 1. A. Ovule included in paraffin, showing synergids (Si) and polar nucleus (PN) polarization. B. Ovule clarified, arrow showing a string with starch grains, disposed until chalazal portion. C. Ovule under polarized light showing bright starch grains. D. Details of starch grains. Bars $=6 \mu \mathrm{m}$. 
development of the embryo sac, could be seen. In clarified ovules starch grains could be seen (figure 1B), always disposed around the polar nucleus, involving the central cell and occupying the majority of the embryo sac (figure 1C, D).

The majority of ovules collected at 24 HAP did not show indications of gamete fusion (figure $2 \mathrm{~A}$ ). The oosphere appeared as more developed, when compared with the previous phase (pre-anthesis), with a discrete enlargement of the nucleus in posterior phases (figure 3A, B, C). In ovules that showed indications of spermatic delivery, the pollen tube was always received by synergids, which promptly begun to degenerate (figure 3D, E). During this phase, synergids still were in contact with the nucellus. In some ovules it was possible to observe the two spermatic nuclei in the synergids, before these migrated towards the oosphere and polar nuclei (figure 3F).

Although $70 \%$ of the ovules did not show evidences of gametic fusion, some cases were observed with a spermatic nucleus on the side of the oosphere or at the polar nucleus, or the formation of the first endosperm nucleus, or additionally, of a zygote with two nucleolates.

Ovaries collected at 48 HAP showed a different behavior depending on the crossing performed. In compatible crossings, only $35 \%$ of ovules did not show evidences of a gametic fusion, with the female gametophyte showing only the oosphere, the synergids and the polar nucleus. In incompatible crossings, this number rose to $50 \%$ (figure $2 \mathrm{~B}$ ). In ovules without evidences of fertilization, the nucellus did not show evidences of having been consumed. Ovules were observed showing a fusion of one of the spermatic nuclei with the polar nucleus (figure 4A), for the formation of the primary endosperm nucleus (figure 4B) and its division for the formation of the free spermatic nucleus (figure 4C) or even, the pro-zygote with two nucleolates. In fecundated ovules, the nucellus began to be consumed from its chalazal portion (figure 4D). The starch grains were still present and the presence of pollen tubes was also observed. The difference between compatible and incompatible crossings began to be shown, but was not significant according to the applied statistical test.

At 72 HAP around $1.2 \%$ and $14.2 \%$ of ovules from flowers respectively submitted, to compatible and incompatible crossings, showed only the egg apparatus and the two polar nuclei (figure $2 \mathrm{C}$ ). In ovules of the two types of crossings, the presence of the endosperm nucleus was common (figure 5A), with the male gamete close to the egg cell and, in some ovules, the oosphere apparently fertilized and the zygote binucleolate (figure 5B). However, the zygote remained undivided.

In both types of crossings, the entrance of the pollen tube, the delivery of the gametes and posterior polar nucleus fusion for the formation of the primary endosperm nucleus (EPN) were observed. At this stage, a clear difference between compatible and incompatible crossings was observed, with the number of zygote and endosperm $(\mathrm{Zy}+\mathrm{En})$ considered superior in compatibles.

In all observed ovules, the entrance of the pollen tube for gametes delivery occurred by micropyle (porogamy). In only one ovule was an irregular disposition of the egg apparatus observed; it was at the center of the female gametophyte (figure 5C). Despite this, the pollen tube had a normal growth through the micropyle and, afterwards, crossed the nucellus to find synergids.

\section{Discussion}

In cupuassu the embryo sac apparently is of the Polygonum type with ephemerous antipodals, corroborating the classification of Johri et al. (1992) for Sterculiaceae. In addition, the presence of starch grains was common and involved the polar nucleus, defined by Martison (1972) as globular corpuscles.

According to Knight \& Rogers (1955) and Cope (1962) in Theobroma cacao L. the pollen tubes from compatible and incompatible parents have a equal growth rate and deliver their spermatic cells at the megagametophyte, but incompatible gametes fail in the fusion process with the egg cell, where the incompatible reaction apparently occurs. Seavey \& Bawa (1986) and Gibbs (1988) mention works that show the relation and the selection made by the maternal tissue to delay and/ or restrict access to ovules from self pollinated pollen tubes. Cope (1962) states that, in incompatible crosses of $T$. cacao, the presence of many unfecundated ovules giving a posterior flower abscission is not the result of the delay of the gamete delivery into the female gametophyte, but must be due to a gametophytic reaction occurring on the style. Martinson (1972) observed that in interspecific crossings between $T$. cacao $\times$ $T$. grandiflorum, the proportion of female gametophytes with pollen tubes was higher on ovules fixed at 48 and 72 HAP than on those fixed at 24 HAP. In intraespecific crossings, ovules showed the pollen tubes at 24 HAP, so, in those crossings, which are usually incompatible, a delay in the pollen tube growth would occurr.

In cupuassu, independently of the kind of crossing, the presence of pollen tubes on 24 HAP fixed ovules was observed, nevertheless these had not yet delivered 

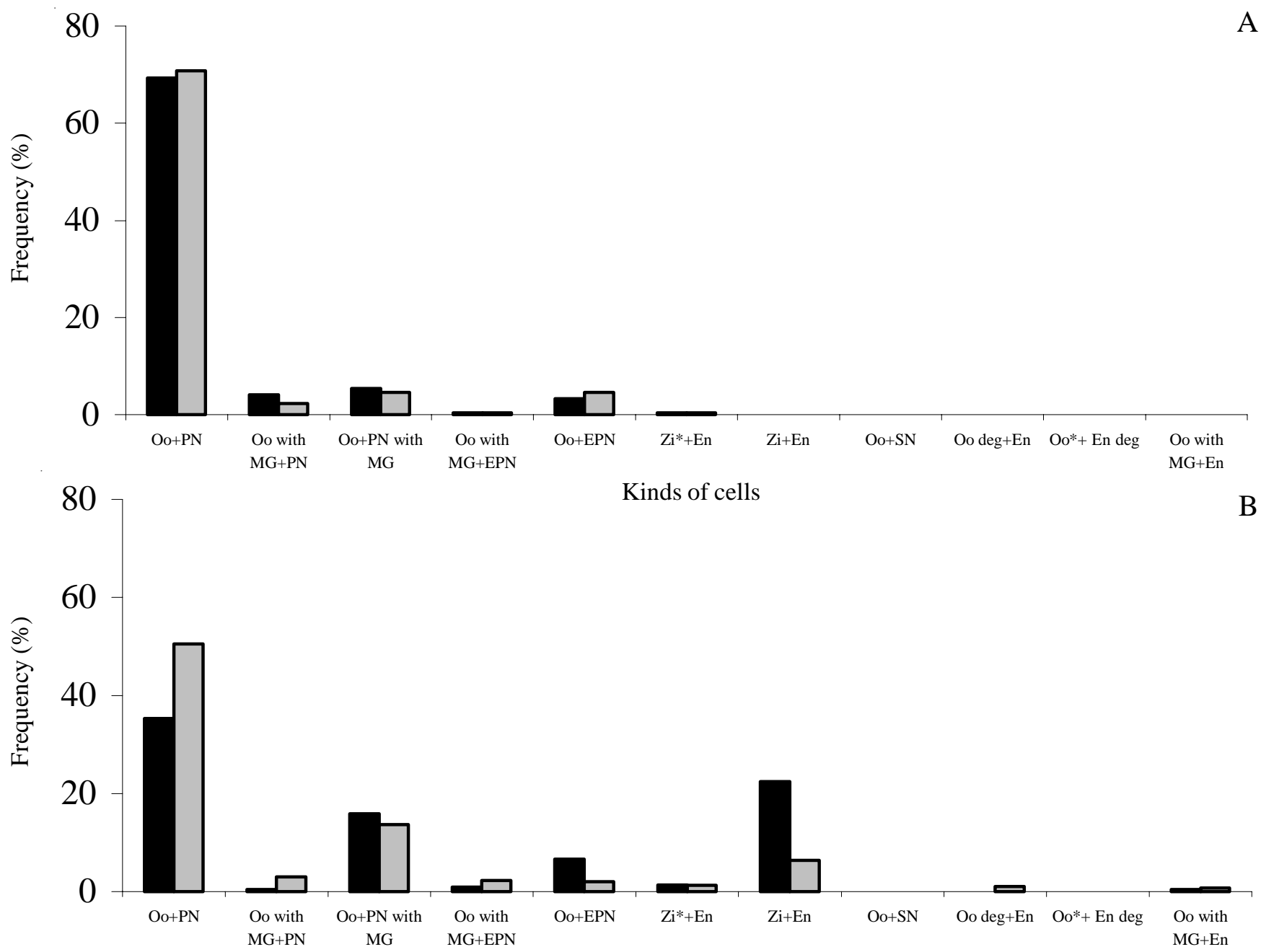

Kinds of cells

$\mathrm{C}$

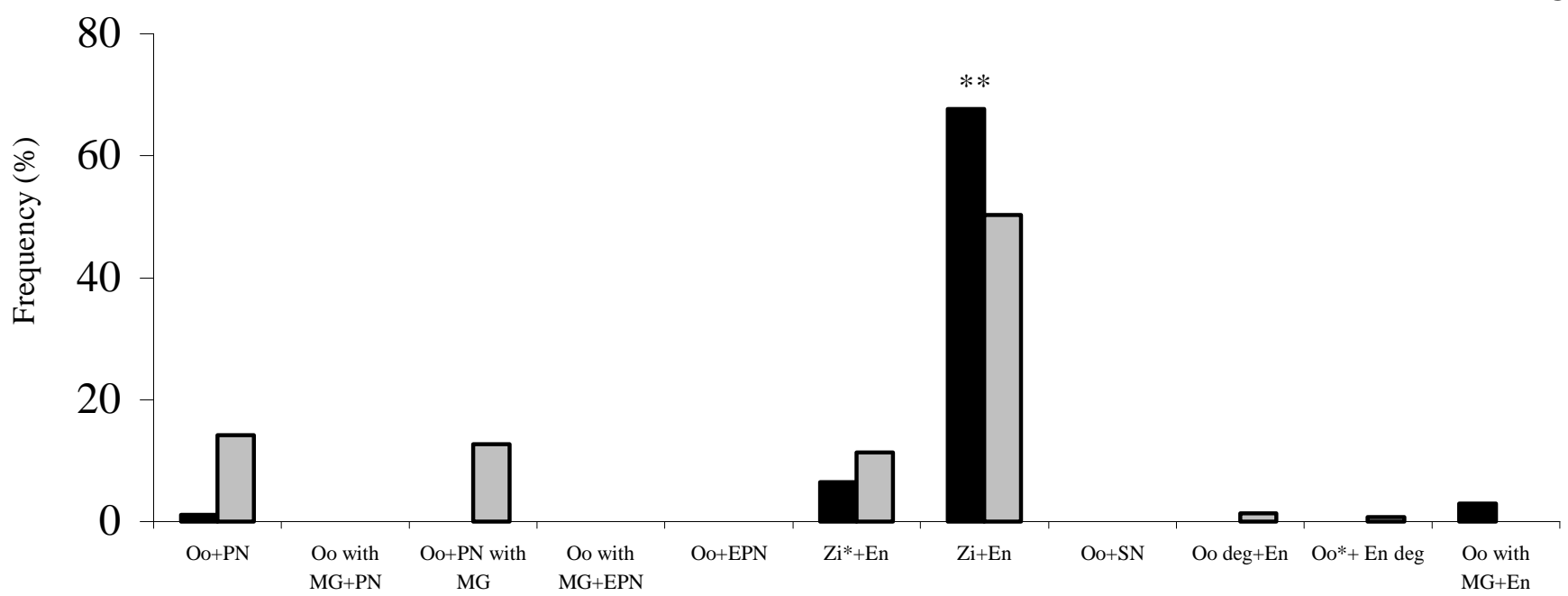

Kinds of cells

Figure 2. Frequency of cells encountered in the embryo sac from flowers submitted to compatible and incompatible pollinations, collected in different times: A. 24 hours after pollination - HAP. B. 48 HAP. C. 72 HAP. Oosphere (Oo), oosphere less developed $\left(\mathrm{Oo}^{*}\right)$, polar nuclei $(\mathrm{PN})$, secondary nucleus $(\mathrm{SN})$, male gamete $(\mathrm{Gm})$, primary endosperm nucleus $(\mathrm{PEN})$, zygote $(\mathrm{Zi})$, zygote with two nucleolates $\left(\mathrm{Zi}^{*}\right)$, endosperm (En), degenerated (deg). The kinds of cells at the " $\mathrm{X}$ " axis are listed, from left to right, in the way to zygote formation or degeneration after pollination. ** Statistically different at $\alpha=0,001 . \boldsymbol{\square}=$ Compatible; $\square=$ Incompatible. 
the spermatic nuclei at the synergids, nor had they inhibited pollen tube growth on the stigma or style. Venturieri (1994) observed that at 12 HAP the pollen tubes could be seen in the ovary without evidences of suffering any incompatibility reaction. Thus, based on these observations, sporophytic and gametophytic incompatibility reactions can be discarded. The incompatibility reaction in cupuassu was shown after this period, at 72 HAP. The delay in pollen tube arrival was observed in interespecific crossings made by Martinson (1972) and in the present work, and so could be interpreted as an analogous mechanism, where the tissue of the pistil would be retarding the growth of incompatibles pollen tubes that are able to delivery their spermatic nuclei only after the compatible ones.

Willemse \& Van Went (1984) state that the zygote remains latent during some time, suffering changes in the nucleus and cytoplasm, while the endosperm is developing. The latency of the zygote is a characteristic that can be observed in other species, such as Vellozia leptopetala Goeth. \& Henrard, V. caruncularis Mart. ex Seub. and Barbacenia flava Mart. ex Steud. var. flava, which remain up to 10 days after pollination with the zygote undivided (Castro 1998). Cope (1962) and Martinson (1972) observed that the zygote of cocoa remained undivided up to $72 \mathrm{HAP}$, which also occurs in cupuassu.

The division of the zygote occurs at variable times, but at the fertilized central cell the primary endosperm nucleus (EPN) divides very fast. In cocoa, in both types of crossings the male gametes that fuse with the polar nucleus to form the EPN are easily observed inside the ovule (Knight \& Rogers 1955). In cupuassu, one of the male gametes could also be seen at the side of the polar nucleus and also the fusion of these nucleus to form the EPN. In a high number of ovules, three still individualized nucleoli were observed. According to Willemse \& van Went (1984), fusion of the nucleoli occurs shortly after the nuclear fusion indicated by the complementation of chromatin. In cupuassu, endosperm nuclei were easily recognized, both in incompatible and compatible crossings.

According to Cope (1962), cocoa flowers submitted to incompatible pollination at the time of abscission,
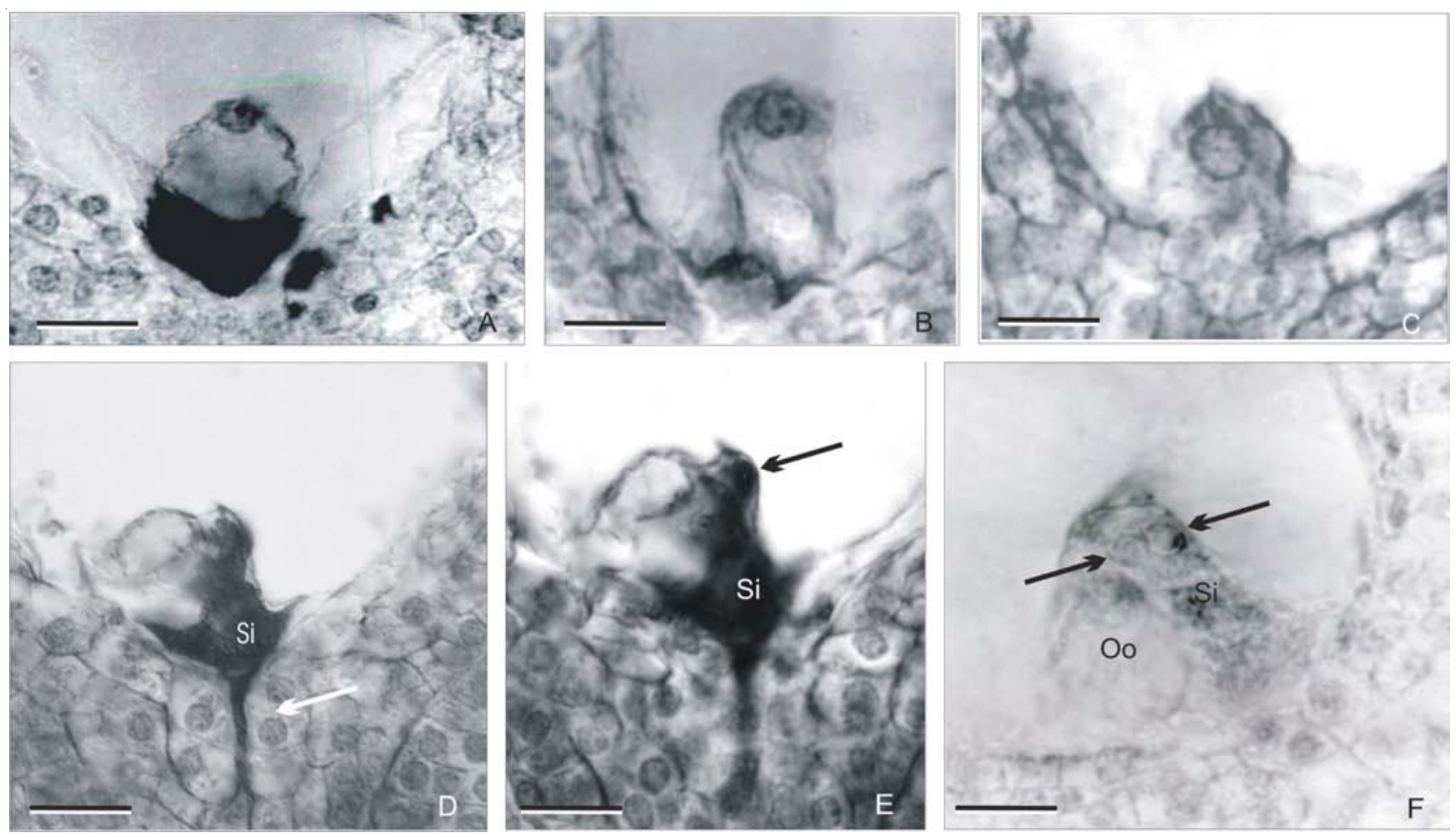

Figure 3. A. Ovule in pre-anthesis with undeveloped oosphere. B and C. Receptively ovules with 24 and 72 hours after pollination - HAP with more developed oospheres. D. Ovule with 24 HAP, synergid (Si) receiving a pollen tube. The arrow shows a micropyle with a pollen tube. E. Ovule with 24 HAP, arrow shows spermatic nucleus delivery at synergids. F. Ovule with 48 HAP, arrow shows 2 spermatic nuclei in synergids (Si) behind oosphere (Oo). Bars $=6 \mu \mathrm{m}(\mathrm{A}-\mathrm{C}$ and F); $9 \mu \mathrm{m}(\mathrm{D}, \mathrm{E})$. 

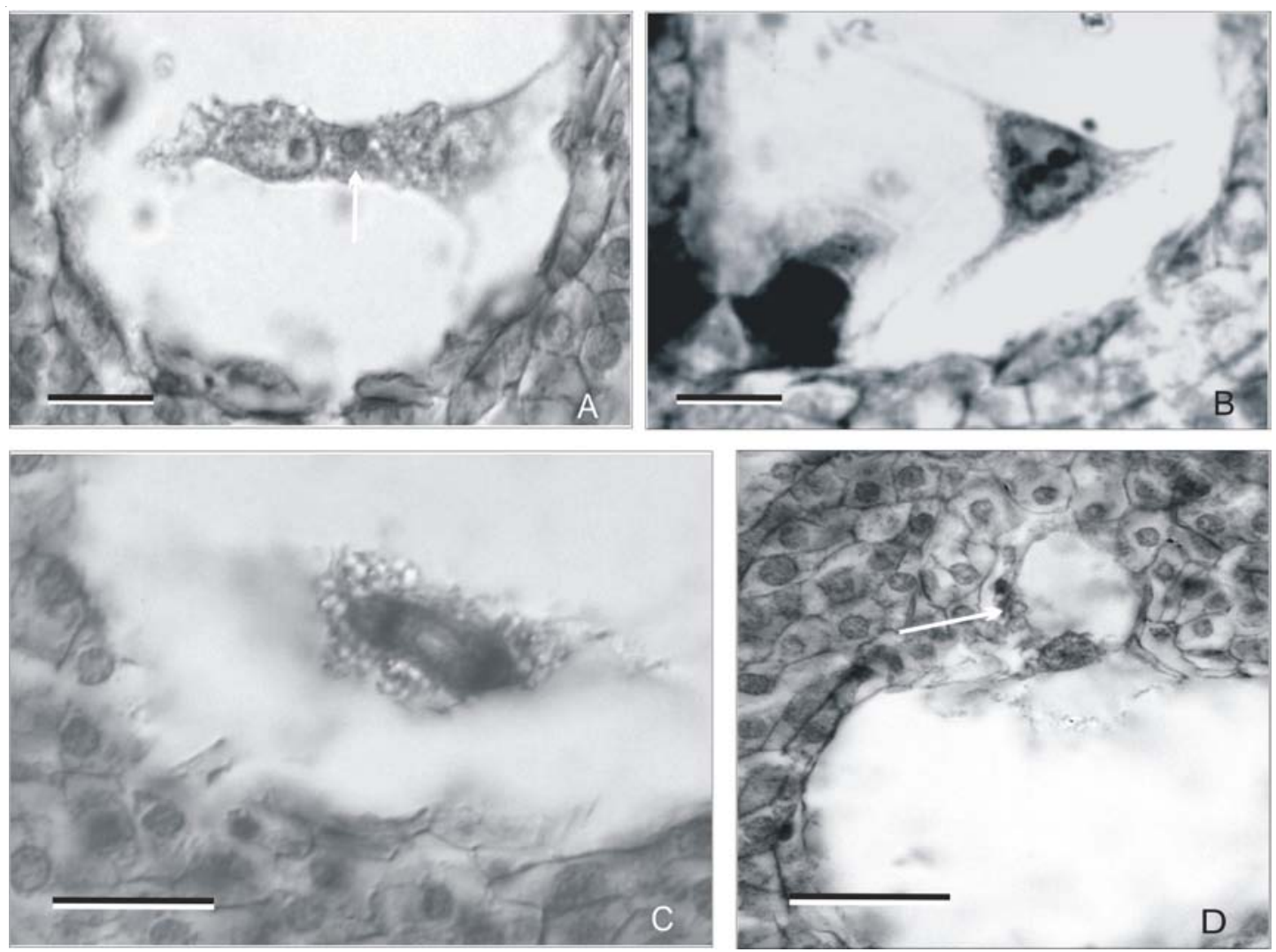

Figure 4. A. Ovules showing a fusion of one of the spermatic nuclei with the polar nucleus, (white arrow). B. Formation of the primary endosperm nucleus. C. Division for the formation of the free spermatic nucleus. D. The nucellus beginning to be consumed from its chalazal portion. Bars $=6 \mu \mathrm{m}(\mathrm{B}) ; 9 \mu \mathrm{m}(\mathrm{A}, \mathrm{C}, \mathrm{D})$.

showed ovules with a male gamete that did not fuse with the oosphere, and the 2nd male gamete that did not fuse with the polar nuclei. In ovules that showed male and female gamete fusion, with a common binucleolate zygote, the 2nd gamete was fused with the polar nucleus; nevertheless, no posterior divisions were seen. In cupuassu, ovules that received incompatible pollen tubes formed the EPN, which divided immediately to form the free endosperm nuclei, which could be, at first glance, be seen as another evidence that the selfincompatibility mechanisms of cocoa and cupuassu are distinct. Cope (1962) suggests a gametophytic sporophytic system for cocoa, with a reaction occurring inside the female gametophyte, while Seavey \& Bawa (1986) suggest that for cocoa there is a late selfincompatibility action, with the inhibition occurring already in the ovary, but before fertilization.

Cytological observations made with cupuassu show that the male gametes are being delivered in synergids and fusing with the polar nucleus, to form the endosperm. In Chorisia spp., Tabebuia spp., Gasteria verrucosa
Duval, Rhododendron spp. and Asclepias exaltata L., the sperm nuclei are delivered from incompatible pollen tubes and triple fusion seems to be occurring, indicating the beginning of the development of endosperm. In these species syngamy also seems to occur, but the supposed zygote never divides (Sage et al. 1994). In cupuassu, there was the formation of endosperm in the two types of crossings and some zygotes with two nuclei were observed, but the majority of ovules did not show differences in the oosphere. Only a discrete increase in the egg cell nucleus volume could be observed. If the formation of the endosperm serves as confirmation of the gametic fusion, as proposed by some authors (Chasan \& Walbot 1993), the incompatibility reaction in cupuassu, would occurr after the gametic fusion. Self fertilization with the division of the endosperm but not the zygote was described also for Gasteria sp. (Sears 1937), Asclepias syriaca L. (Sparrow \& Pearson 1948), Rhododendron spp. (Williams et al. 1984), Vellozia squamata Pohl (Oliveira et al. 1991), Tabebuia and Chorisia (Gibbs \& Bianchi 1993). 

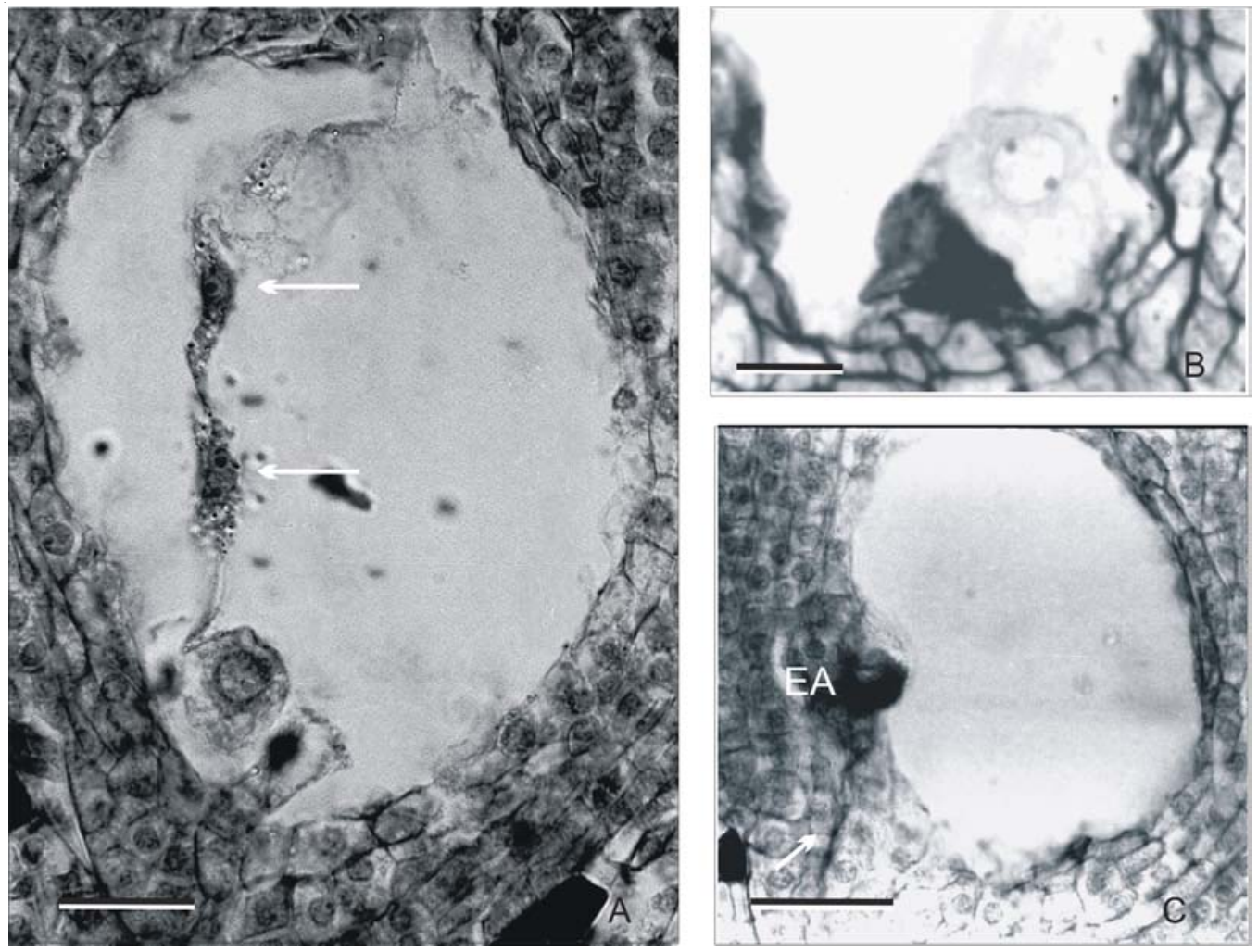

Figure 5. A. Endosperm nuclei (white arrow). B. Zygote binucleolate. C. Ovule with an irregular disposition of the egg apparatus, arrow showing the way of pollen tube. EA = egg apparatus. Bars $=6 \mu \mathrm{m}(\mathrm{B}) ; 9 \mu \mathrm{m}(\mathrm{A})$; and $16 \mu \mathrm{m}(\mathrm{C})$.

Ovules from flowers collected at 72 HAP showed the beginning of the degradation of nucellus. The consumption of the nucellus at this stage could be associated with a higher metabolic activity, since that the endosperm was in process of division, with the formation of free nuclei. The zygote, in this phase, still was undivided, but could be synthesizing necessary substances for further phases. For the elucidation of these aspects, more detailed studies, with ultra structural observation would be necessary, since that egg cell has different aspects from those of the oosphere (Willemse \& van Went 1984), as a result of changes in the metabolism for formation of the embryo (Natesh \& Rau 1984, Willemse \& van Went 1984, Russell 1993). These ultra structural studies could confirm the success or failure of these species where the zygote remains undivided for some time after its formation.

In summary, gamete fusion in cupuassu possibly occurs between 48 to 72 HAP. In ovaries collected at 72 HAP, one could observe: i) in compatible crosses, a low percentage of ovules without indications of gamete fusion; ii) in incompatible crosses, a higher number of ovules without indications of gamete fusion, which could be explained by two factors acting simultaneously. These would be the delay in incompatible pollen tube growth, similar to what occurs in cocoa and an inhibition at ovular level occurring before fertilization, as proposed by Seavey \& Bawa (1986).

A comparative histochemical analysis between ovules from flowers submitted to compatible and incompatible crossings, collected at 48 and 72 HAP could indicate, during the process of development of the zygote, how the liberation of nutrients could occur, that is, if proteins, carbohydrates or lipids would be blocked or synthesized and how this could possibly be associated with abortion of these flowers. The precise identification of these substances could give clues as to where and how genetic control of the incompatibility could act.

After the identification of these substances, it would be possible to know at what moment these genes are being expressed and, by a program of genetic engineering, to try to silence them and, consequently, inhibit the production of abortive substance, or incorporate transgenes that could continue the process of synthesis of substances vital to the development of the ovule, thus forming self- compatible varieties. 
Acknowledgements - Studies financed by the National Council for Scientific and Technological Development (CNPq)/Program for the Humid Tropics (PTU) (proc. 63.00.13/95-0) and by the International Foundation for Science (IFS) grant no. D/2456-1.

\section{References}

BERBERT, P.B.R.F. 1981. Determinação do teor, ácidos graxos e características físicas das gorduras das sementes de Theobroma grandiflorum L. e do Theobroma bicolor L. e comparação com a gordura do Theobroma cacao L. Revista Theobroma 11:91-98.

CASTRO, N.M. 1998. Desenvolvimento de óvulos e aspectos da biologia da reprodução de espécies de Velloziaceae da Serra do Cipó (MG). Tese de doutorado, Universidade de São Paulo, São Paulo.

CHASAN, R. \& WALBOT, V. 1993. Mechanisms of plant reproduction: questions and approaches. The Plant Cell 5:1139-1146.

CLEMENT, C.R. \& VENTURIERI, G.A. 1990. Bacuri and cupuassu. In Fruits of tropical and subtropical origin: composition, properties, uses. (S. Nagy, P.E. Shaw \& W. Wardowski, eds.). Florida Science Source, Florida, p.178-192.

COPE, F.W. 1962. The mechanism of pollen incompatibility in Theobroma L. Heredity 17:157-182.

CUATRECASAS, J. 1964. Cacao and its allies: a taxonomic revision of the genus Theobroma. Contribution from the United States National Herbarium 35:379-614.

CUCO, S.M. 1992. Citogenética da seringueira Hevea brasiliensis (Wild. ex Adr. de Juss.) Muell. Arg. Dissertação de mestrado, Universidade de São Paulo, Piracicaba.

CUCO, S.M. 1997. Caracterização citomorfologia da seringueira (Hevea brasiliensis (Willd. ex Adr. de Juss.) Muell. Arg.). Tese de doutorado, Universidade de São Paulo, Piracicaba.

DIAS, L.A.S. \& REZENDE, M.D.V. 2001. Estratégias e métodos de seleção. In Melhoramento genético do cacaueiro. (L.A.S. Dias, ed.). Fundação de apoio a pesquisa da Universidade Federal de Goiás / Universidade Federal de Viçosa, p. 217-287.

FALCÃO, M.A. \& LLERAS, E. 1983. Aspectos fenológicos, ecológicos e de produtividade do cupuaçu (Theobroma grandiflorum (Willd. ex Spreng.) Schum.). Acta Amazonica 13:725-735.

FREE, J.B. 1993. Insect pollination of crops. Academic Press, New York.

GIBBS, P.E. 1988. Self-incompatibility mechanisms in flowering plants: some implications and clarifications. Lagascalia 15:17-28.

GIBBS, P.E. \& BIANCHI, M. 1993. Post-pollination events in species of Chorisia (Bombacaceae) and Tabebuia (Bignoniaceae) with late-acting self-incompatibility. Botanica Acta 106:64-71.
JAHIER, J. 1992. Techniques de cytogénétique végétale. INRA, Paris.

JOHRI, B.M., AMBEGAOKAR, K.B., SRIVASTAVA, P.S. 1992. Comparative embryology of angiosperms. SpringerVerlag, Berlin.

KNIGHT, R. \& ROGERS, H.H. 1955. Incompatibility in Theobroma cacao. Heredity 9:69-72.

MARTINSON, V. 1972. Embryological studies on hybridisation between Theobroma cacao and Theobroma grandiflorum. Canadian Journal of Botany 50:2117-2124.

NATESH, S. \& RAU, M.A. 1984. The embryo. In Embryology of angiosperms. (B.M. Johri, ed.). Springer-Verlag, New York, p.377-443.

OLIVEIRA, P.E., GIBBS, P.E. \& BIANCHI, M. 1991. Pollination and breeding system of Vellozia squamata (Liliales: Velloziaceae): A species of the brazilian cerrados. Botanical Acta 104:392-398.

RODRIGUES, A.A. \& VENTURIERI, G.A. 1997. Comportamento floral de cupuí (Theobroma subincanum). In Anais do I Encontro de Botânica de Espécies Nativas da América Latina, Instituto Agronômico de Campinas / Centro Nacional de Recursos Genéticos, Campinas, p.67.

RUSSELL, S.D. 1993. The egg cell: Development and role in fertilization and early embryogenesis. The Plant Cell 5:1349-1359.

SAGE, T.L., BERTIN, R.I. \& WILLIAMS, E.G. 1994. Ovarian end other late acting self-incompatibility systems. In Genetic control of self-incompatibility and reproductive development in flowering plants. (E.G. Williams, E.C. Adrienne \& R.B. Knox, eds.). Kluwer Academic Publishers, Dordrecht, p.116-140.

SEARS, E.R. 1937. Cytological phenomena connected with self-sterility in the flowering plants. Genetics 22:130-181.

SEAVEY, S.R. \& BAWA, K.S. 1986. Late-acting Selfincompatibility in Angiosperms. The Botanical Review 52:195-219.

SIEGEL, S. 1975. Estatística não paramétrica (para ciências do comportamento), McGraw-Hill, São Paulo.

SPARROW, F.K. \& PEARSON, N.L. 1948. Pollen compatibility in Asclepias syriaca. Journal of Agricultural Research. 77:187-199.

VAN WENT, J.L. \& WILLEMSE, M.T.M. 1984. Fertilization. In Embryology of angiosperms. (B.M. Johri, ed.). Springer-Verlag, New York, p.273-317.

VENTURIERI, G.A. 1993a. Cupuaçu: A espécie, sua cultura, usos e processamento. Clube do Cupu, Belém.

VENTURIERI, G.A. 1993b Cupuassu (Theobroma grandiflorum, Sterculiaceae). In Income generation forests and conservation in amazoni $a$ (J.W. Clay \& C.R. Clement, eds.). FAO Forestry Papers, Rome, p.147-158.

VENTURIERI, G.A. 1994. Floral Biology of cupuassu (Theobroma grandiflorum (Willdenow ex Sprengel) Schumann). PhD Thesis, University of Reading, Reading, 
VENTURIERI, G.A. \& AGUIAR, J.P.L. 1988. Composição do chocolate de amêndoas de cupuaçu (Theobroma grandiflorum). Acta Amazonica 18:3-8.

VENTURIERI, G.A. \& RIBEIRO FILHO, A.A. 1995. A polinização manual no cupuaçuzeiro (Theobroma grandiflorum (Willdenow ex Sprengel) Schumann). Acta Amazonica 25:181-191.
WILLEMSE, M.T.M. \& VAN WENT, J.L. 1984. The Female gametophyte. In Embryology of angiosperms. (B.M. Johri, ed.). Springer-Verlag, New York, p.159-196.

WILLIAMS, E.G., KAUL, V., ROUSE, J.L. \& KNOX, R.B. 1984. Apparent self-incompatibility in Rhododendron ellipticum, $R$. championae and $R$. amamiense: A post-zygotic mechanism. Plant Cell Incompatibility Newsletter 16:10-11. 